\title{
Analisis Kelayakan CVT (Capacitive Voltage Transformer) Phasa S Bay Busbar 2150 kV di GI PT. XYZ Indonesia
}

\author{
Suciani Rahma Pertiwi ${ }^{1}$, Ulinnuha Latifa ${ }^{2}$, Rahmat Hidayat ${ }^{3}$, Ibrahim ${ }^{4}$ \\ 1,2,3Program Studi Teknik Elektro, \\ Fakultas Teknik, \\ Universitas Singaperbangsa Karawang \\ ${ }^{1}$ suciani.rahma17017@student.unsika.ac.id, ${ }^{2}$ ulinnuha.latifa@ft.unsika.ac.id, \\ ${ }^{3}$ rahmat.hidayat@staff.unsika.ac.id, ${ }^{4}$ ibrahim@ft.unsika.ac.id
}

\begin{abstract}
Abstrak
Transmisi pada gardu induk sudah banyak dikenal sebagai penyaluran tenaga listrik. Salah satu bagiannya yaitu Transmisi Gardu Induk yang betugas sebagai sarana penghubung aliran listrik antara bagian pembangkit dan distribusi sebelum dialirkan ke konsumen. Tidak hanya itu, bagian transmisi gardu indukpun bertugas untuk menaikan atau menurunkan tegangan listrik. Sebab itulah Transmisi Gardu Induk menjadi bagian penting dalam terciptanya listrik yang sampai pada konsumen dan Transmisi Gardu induk merupakan aset negara yang terjaga dan tidak boleh sembarang orang yang masuk. Salah satu peralatan pada gardu induk ialah CVT (Capacitive Voltage Transformer) yang bertugas sebagai alat proteksi yang mentransformasikan besaran tegangan sistem dari yang tinggi ke besaran tegangan listrik yang lebih rendah sehingga pengukuran menajdi lebih aman, akurat dan teliti. Karena CVT merupakan salah satu alat penting pada gardu induk, penelitian ini memberikan analisis saat pemeliharaan CVT guna terjaganya kelayakan performa CVT tersebut dengan melakukan 3 pengujian yaitu pengujian pentanahan, tahanan isolasi, dan tan delta.
\end{abstract}

Kata kunci: gardu induk, transmisi, CVT, listrik

\begin{abstract}
Transmission at the substation is widely known as the distribution of electric power. One part of it is the substation transmission which acts as a means of connecting the flow of electricity between the generator and distribution parts before it is supplied to consumers. Not only that, the substation transmission section is responsible to increase or decrease the amount of electric voltage. Therefore, substation transmission is an important part in the generation of electricity that reaches consumers and substation transmission is also a protected state asset and not everyone may enter. One of the equipment at the substation is the CVT (Capacitive Voltage Transformer) which serves as a protective device that transforms the system voltage from a high to a lower electrical voltage so that the measurement becomes safer, more accurate and precise. Since CVT is one of the important tools at the substation, this study conduct analysis on CVT maintenance in order to maintain the proper performance of the CVT by carrying out 3 tests, namely ground testing, insulation resistance, and tan delta.
\end{abstract}

Keywords: substation, transmission, CVT, electricity 


\section{Pendahuluan}

Sistem tenaga listrik terbagi menjadi 3 bagian sistem yaitu sistem pembangkit, sistem transmisi Gardu Induk dan sistem distribusi. Gardu induk merupakan sub sistem dari sistem penyaluran (transmisi) tenaga listrik, atau merupakan satu kesatuan dari sistem penyaluran (transmisi) [1]. Definisi untuk gardu induk ialah satu koherensi dari sistem transmisi, atau merupakan sebuah tempat yang di mana diletakkannya peralatan peralatan induk pentransmisian berupa peralatan yang berfungsi sebagai kontrol, menaikan dan menurunkan tegangan, alur penghubung tegangan lsitrik, dan proteksi. Salah satu contoh peralatan yang berada pada gardu induk ialah CVT atau Capacitive Voltage Transformer.

CVT atau sering disebut dengan trafo tegangan adalah sumber utama sinyal tegangan untuk monitoring dan peralatan yang mentransformasi tegangan sistem yang lebih tinggi ke suatu tegangan sistem yang lebih rendah untuk kebutuhan peralatan indikator, alat ukur atau meter, relai proteksi, dan aplikasi kontrol sistem HV dan EHV [2][8]. CVT dapat digunakan pengukuran yang lebih pasti dan cermat, peralatan proteksi dan pengisolasian yang mana meskipun bagian primer memiliki tegangan yang sangat tinggi dengan perbedaan pada bagian sekunder yang memiliki tegangan rendah tetap dapat dipakai sebagai alat sistem proteksi dan pengukuran peralatan di bagian primer. Peran CVT dalam sistem kelistrikan sangat vital, terutama untuk sistem pengaman dan pengukuran [3]. Maka dari itu CVT adalah salah satu peralatan penting yang berada di Gardu Induk dan harus dijaga performanya.

Untuk menjaga performa dari CVT maka uji kelayakan CVT sangatlah penting untuk melihat apakah CVT masih layak dipakai atau tidak, guna meminimalisir hal - hal yang tidak diinginkan seperti hilangnya tegangan secara cuma- cuma yang akan menimbulkan penurunan tegangan dan kerugian bagi Perusahaan penjual maupun masyarakat. Ini dilakukan agar tidak adanya gangguan dan terjaganya tingkat performa pada CVT itu sendiri. Pengujian - pengujian ini akan menunjukan kelayakan CVT sesuai dengan pengujian - pengujian yang sudah terstandarisasi guna terjaminnya pentransmisian listrik yang akan sampai ke bagian distribusi, perusahaan ataupun konsumen. Maka dari itu, penelitian ini menjelaskan tentang cara pengujian - pengujian yang dilakukan pada CVT Phasa S Bay Busbar $2150 \mathrm{kV}$ di GI PT. XYZ Indonesia yang telah terstandarisasi untuk melihat performa kelayakannya.

\section{Konsep Dasar}

\subsection{Sistem Transmisi}

Transmisi tenaga listrik merupakan proses penyaluran tenaga listrik dari tempat pembangkit tenaga listrik (Power Plant) hingga substansi distribusi sehingga dapat disalurkan sampai pada konsumer pengguna listrik melalui suatu bahan konduktor [4], seperti ditunjukkan Gambar 1. Tegangan $500 \mathrm{kV}$ yang telah dinaikan oleh trafo daya yang ada pada umumnya berasal dari tegangan awal yang rendah yaitu antara $6 \mathrm{kV}$ sampai 24 $\mathrm{kV}$. Tingkat tegangan yang lebih tinggi ini selain untuk memperbesar daya hantar saluran yang berbanding lurus dengan kuadrat tegangan, juga untuk memperkecil rugi-rugi daya dan jatuh tegangan pada saluran [7]. Kenaikan ini dibuat karena energi listrik yang telah dibangkitkan wajib dialirkan menggunakan saluran transmisi, sedangkan biasanya sistem pembangkitan memiliki jarak yang jauh dari tempat-tempat di mana energi listrik tersebut dapat dipakai. 


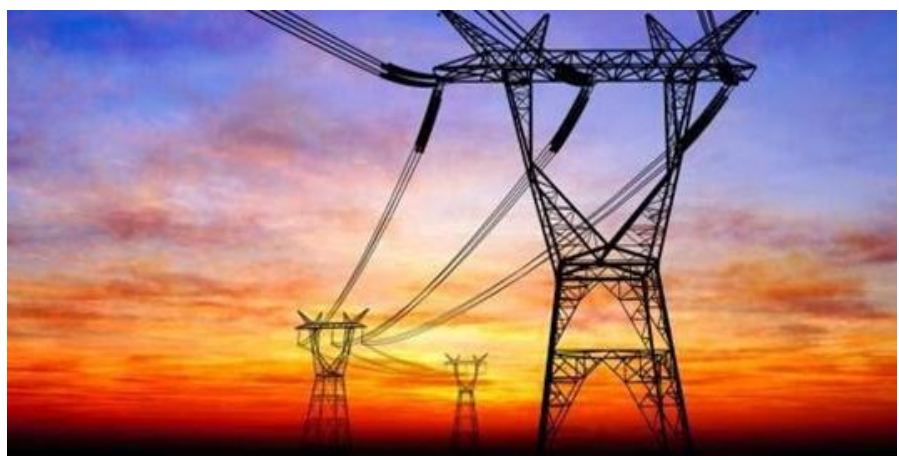

Gambar 1. Sistem transmisi

Kebutuhan energi listrik yang terus bertambah membuat banyak dibangunnya pusat tenaga listrik yang memiliki kapasitas besar dan pada umumnya pembangunan pusat tenaga listrik itu memiliki jarak yang jauh dari pusat pemukiman masyarakat (konsumen) karena beberapa alasan seperti masalah sosial, geografis, ekonomi dan potensi alam. Oleh karena itu, penyalurkan energi dari pusat pembangkit kepada konsumen membutuhkan peralatan tegangan tinggi dan saluran atau transmisi tegangan tinggi yang mendukung pengadaan transmisi tegangan tinggi tersebut, seperti ditunjukkan Gambar 2.

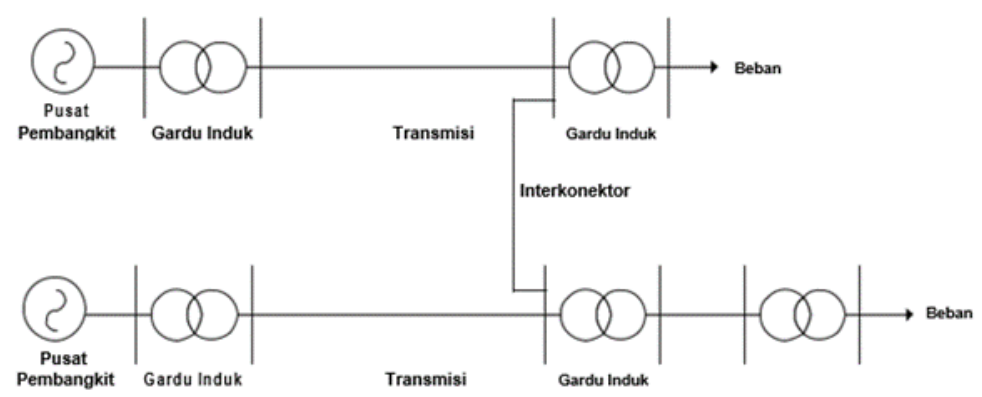

Gambar 2. Diagram garis sistem tenaga listrik

Berdasarkan jarak atau panjangnya, saluran transmisi dapat dibedakan menjadi tiga, yaitu:

1. Saluran transmisi jarak pendek (short line), adalah saluran yang panjangnya kurang dari $80 \mathrm{~km}$.

2. Saluran transmisi jarak menengah (medium line), adalah saluran yang panjangnya antara $80-240 \mathrm{~km}$.

3. Saluran transmisi jarak jauh (long line), adalah saluran yang panjangnya lebih dari $240 \mathrm{~km}$.

Daya listrik akan selalu mengalir menuju beban karena itu dalam hal ini aliran daya juga merupakan aliran beban. Beban - beban itu direpresentasikan sebagai impedans tetap $(Z)$, sebagai daya tetap $(S)$, tegangan $(V)$ ataupun arus $(I)$ yang tetap yang lazim pembebanan dipilih menggunakan tegangan yang konstan. Pada saluran transmisi tegangan ekstra tinggi terdapat rugi - rugi tegangan dan rugi - rugi daya yang disebabkan 
oleh beberapa faktor di antaranya adalah faktor korona dan faktor kebocoran isolator yang biasanya banyak terjadi pada saluran transmisi tegangan ekstra tinggi, sehingga mengakibatkan tegangan mengalami penurunan atau biasa disebut dengan jatuh tegangan. Hal ini terjadi apabila tegangan pada pangkal pengiriman dengan tegangan pada ujung penerimaan ada perbedaan [10].

Di setiap negara ataupun perusahaan listrik pun memiliki besaran jumlah saluran transmisi yang berbeda - beda karena kemajuan teknik di setiap negara yang berbeda beda pula. Berikut adalah klasifikasi tegangan tinggi secara umum di Indonesia.

1. Tegangan Tinggi (High Voltage), yaitu tegangan sistem $36 \mathrm{kV}-150 \mathrm{kV}$ [11].

2. Tegangan Ekstra Tinggi (Extra High Voltage), yaitu tegangan sistem $200 \mathrm{kV}-500 \mathrm{kV}$ [12].

Pembangkit transmisi memerlukan trafo daya step up sebab transmisi memerlukan tegangan dari puluhan sampai ratusan kilovolt, sebaliknya tegangan yang dibangkitkan generator terbatas hanya dalam belasan kilovolt. Oleh sebab itu, seluruh peralatan yang terpasang disisi sekunder trafo ini wajib sanggup memikul tegangan besar. Di antara transmisi dengan konsumen juga diperlukan trafo daya step down, ini disebabkan karena konsumen memerlukan tegangan dari ratusan volt hingga puluhan $\mathrm{kV}$, sebaliknya tegangan transmisi dari puluhan hingga ratusan $\mathrm{kV}$, sehingga seluruh peralatan yang terpasang di sisi primer trafo ini pula wajib sanggup memikul tegangan besar. Trafo - trafo daya tersebut dan perlengkapan- perlengkapannya adalah gardu induk.

\subsection{Gardu Induk}

Listrik sangat dibutuhkan pada masa ini, dan teknologi sistem tenaga listrik terus bergerak maju. Sistem tenaga listrik adalah sekumpulan pusat listrik dan gardu induk (pusat beban) yang satu dengan yang lain dihubungkan oleh jaringan transmisi dan distribusi sehingga merupakan satu kesatuan yang terinterkoneksi [5].

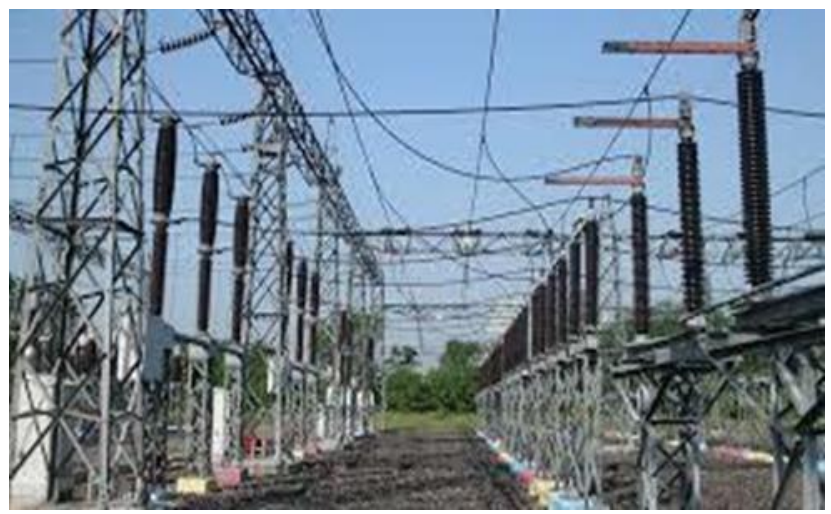

Gambar 3. Gardu Induk

Sedangkan Gardu induk merupakan sub sistem atau merupakan satu koherensi dari sistem penyaluran (transmisi), seperti ditunjukkan Gambar 3. Ini mengandung arti yaitu gardu induk ialah sub-sub sistem dari sistem tenaga listrik. Sebagai sub sistem dari sistem penyulang (transmisi) gardu induk tidak dapat dilepas dari sistem penyaluran (transmisi) secara keutuhan, dan memiliki peran penting dalam pengoprasiannya. Berikut adalah beberapa fungsi gardu induk [1] :

1. Mengubah daya listrik:

a) Dari tegangan ekstra tinggi menjadi tegangan tinggi (500 KV/150 KV) 
b) Dari tegangan tinggi menjadi tegangan yang lebih rendah (150 KV/70 KV)

c) Dari tegangan tinggi menjadi tegangan menengah $(150 \mathrm{KV} / 20 \mathrm{KV}, 70 \mathrm{KV} / 20$ $\mathrm{KV})$

d) Dengan frekuensi tetap (di Indonesia $50 \mathrm{~Hz}$ )

2. Penataan pelayanan beban ke gardu induk-gardu induk lain melewati tegangan tinggi serta ke gardu distribusi - gardu distribusi, sesudah melewati proses penyusutan tegangan melalui penyulang-penyulang (feeder-feeder) tegangan menengah yang terdapat di gardu induk

3. Untuk pengukuran, pengawasan operasi dan pengaman dari sistem tenaga listrik.

4. Untuk sarana telekomunikasi yang pada umumnya untuk internal perusahaan, yang kita tahu dengan sebutan SCADA.

\subsection{CVT (Capacitive Voltage Transformator)}

CVT adalah salah satu alat pada gardu induk yang memiliki peran penting dalam transmisi listrik, seperti ditunjukkan Gambar 4. CVT juga digunakan sebagai alat proteksi pada transmisi tenaga listrik. Proteksi transmisi tenaga listrik adalah proteksi yang dipasang pada peralatan-peralatan listrik pada suatu transmisi tenaga listrik sehingga proses penyaluaran tenaga listrik dari tempat pembangkit tenaga listrik (power plant) hingga saluran distribusi listrik (substation distribution) dapat disalurkan sampai pada konsumen pengguna listrik dengan aman [6].

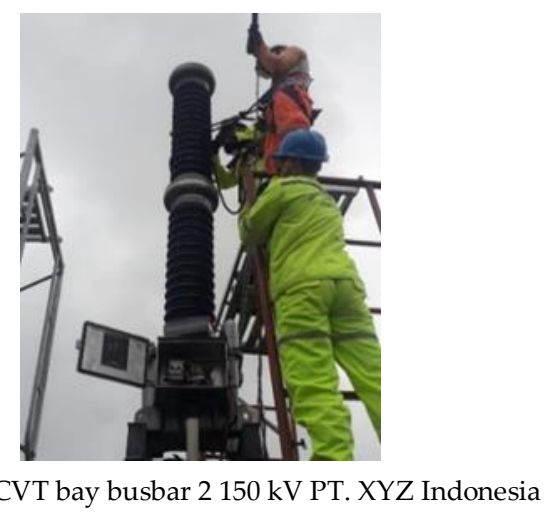

CVT sebagai pembagi tegangan menggunakan pembagi kapasitif tegangan tinggi hanya untuk menurunkan tegangan sekunder ke suatu harga standar sangat tidak ekonomis. Oleh karena itu, pembagi tegangan kapasitif menggunakan sebuah transformator magnetik. Tegangan yang diukur $V u$ dalam orde ratusan kilovolt. Oleh karena pembagi tegangan kapasitor, tegangan pada kapasitor $\mathrm{C} 2$ atau tegangan primer transformator penengah (V1) diperoleh dalam orde puluhan kilovolt, umumnya 5, 10, 15, dan $20 \mathrm{kV}$. Kemudian oleh transformator magnetik, tegangan itu diturunkan lagi menjadi tegangan sekunder standar 100 atau 100 $\sqrt{3}$ [3]. Berikut adalah fungsi dan cara kerja CVT:

\subsubsection{Fungsi CVT}

a) Mengubah jumlah tegangan sistem dari yang tinggi ke jumlah tegangan listrik yang lebih rendah sehingga dapat dipakai untuk perlengkapan proteksi dan pengukuran yang lebih aman dan cermat. 
b) Mengisolasi bagian primer yang mana memiliki tegangan yang sangat tinggi dengan perbedaan pada bagian sekunder yang memiliki tegangan rendah tetap dapat dipakai sebagai alat sistem proteksi dan pengukuran peralatan dibagian primer.

c) Sebagai standarisasi jumlah tegangan sekunder $(100,100 / \sqrt{ } 3,110 / \sqrt{ } 3$ dan 110 volt) untuk kebutuhan peralatan sisi sekunder.

\subsubsection{Cara Kerja CVT}

Sesuai fungsi utama CVT pada Gardu Induk yaitu sebagai metering yang artinya membaca tegangan yang besar pada sisi primer $(\mathrm{kV})$ lalu mentransformasikannya menjadi tegangan yang kecil pada sisi sekunder menggunakan rasio perbandingan agar dapat dibaca di ruang kontrol. Tranformasi ini dilakukan karena ruang kontrol tidak bisa membaca atau belum mampu membaca tegangan dalam skala besar $(\mathrm{kV})$, maka dari itu dibuatlah perbandingan rationya pada sisi sekunder guna bisa terbacanya pada ruang kontrol. Rasio yang di pakai pada CVT umumnya adalah $150000 / \sqrt{ } 3: 100 / \sqrt{ } 3$, di mana $150000 / \sqrt{ } 3$ adalah bagian primer dan $100 / \sqrt{ } 3$ adalah bagian sekunder.

Rasio tersebut pada umumnya telah tertulis pada papan nama (nameplate) CVT yang berada pada bagian belakang CVT, seperti ditunjukkan Gambar 5.

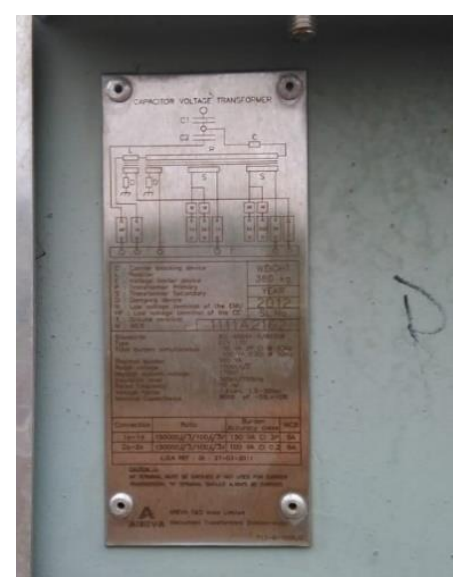

Gambar 5. Papan nama (nameplate) CVT Bay Busbar 2150 kV PT. XYZ Indonesia

Untuk menghitung tegangan yang berada pada sisi sekunder agar bisa terbaca di ruang kontrol di gunakan lah sebuah rumus. Berikut rumus untuk mencari tegangan pada sekunder:

$$
\frac{P}{X}=\frac{150000 / \sqrt{3}}{100 / \sqrt{3}}
$$

Di mana :

$P$ : Tegangan yang terbaca pada sisi primer $(\mathrm{kV})$

$X$ : Tegangan yang ada pada sisi sekunder $(\mathrm{V})$

Persamaan (1) dapat membantu untuk menghitung perbandingan rasio antara sisi primer $(\mathrm{kV})$ dan sisi sekunder $(\mathrm{V})$. Kemudian hasil dari sisi sekunder $(\mathrm{V})$ akan terbaca di ruang kontrol dan bisa dijadikan data tegangan pada gardu induk masih stabil atau tidak dan apakah CVT masih bisa berfungsi dengan baik atau tidak. Berikut contoh soal untuk 
perbandingan rasio sisi primer dan sisi sekunder pada CVT Bay Busbar $2150 \mathrm{kV} \mathrm{PT.} \mathrm{XYZ}$ Indonesia:

Jika diketahui tegangan sisi primer atau tegangan yang berada di gardu induk adalah 150 $\mathrm{kV}$ maka $\mathrm{X}=100$ Volt. Artinya tegangan pada sisi sekunder dan tegangan yang akan terbaca di ruang kontrol adalah $100 \mathrm{~V}$.

\subsubsection{Pengujian Kelayakan CVT}

Pada pengujian ini biasanya dibutuhkan $2-3$ orang pada setiap pengujian. Berikut adalah 3 pengujian untuk melihat kelayakan performa pada CVT :

\subsubsection{Pengujian Pentanahan}

Pengujian pentanahan dilakukan untuk mengetahui grounding masih berkerja dengan baik. Grounding berfungsi sebagai pembuangan aliran listrik yang mengalir dari primer dalam skala yang jauh lebih kecil akibat adanya loncatan potensial listrik yang berada antara sisi primer dan sekunder yang dihalangi oleh isolator. Nantinya loncatan listrik tersebut akan mengalir pada kabel grounding yang terhubung dan akan dibuang ke plat besi (ground rode) yang berada jauh di dalam tanah. Jika grounding ataupun plat (ground rode) tidak berkerja dengan baik maka loncatan listrik tersebut bisa menyebabkan bagian gelagar CVT yang seharusnya tidak bertegangan menjadi bertegangan. Hal ini sangat berbahaya dikarenkan jika ada tim pengujian yang sedang dalam pengecekan dan menyentuh gelagar akan tersengat listrik. Maka perlunya untuk pengujian pentanahan ini.

Pada pengujian tahanan pentanahan ini diuji dengan alat uji pentanahan yaitu Kyoritsu Digital Earth Tester Model 4105A, seperti ditunjukkan Gambar 6. Menurut teori, hasil pengujian tahanan pentanahan diharuskan sesuai dengan standar dari Surat Keputusan Direksi (SK Dir) yang mana telah diberitahukan tentang nominal batas grounding dan batas plat masih berkerja dengan baik. Pada Surat Keputusan Direksi diketahui bahwa grounding harus $<1 \Omega$, jika hasil pengujian pentanahan bernilai $<1 \Omega$ maka grounding dan plat (ground rode) masih bagus.

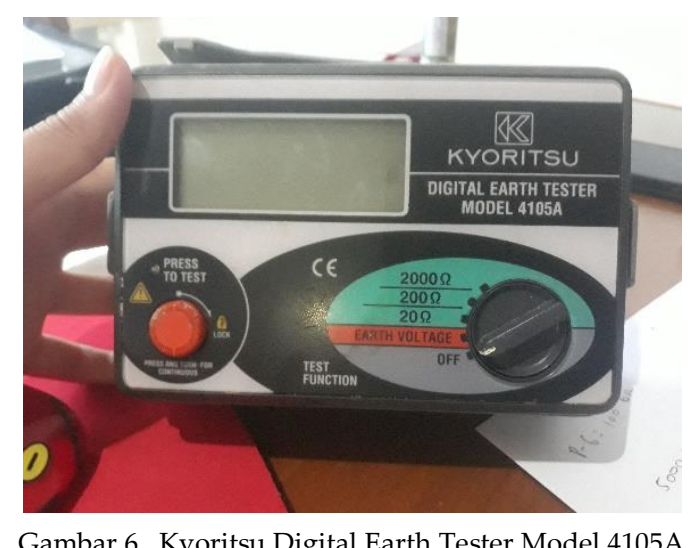

Cara pengujiannya dengan menghubungkan 3 kabel berwarna hijau, merah dan kuning yang berada pada alat uji tahanan pentanahan yaitu Kyoritsu Digital Earth Tester Model 4105A. Kabel hijau akan disambungkan ke kabel grounding CVT dengan cara dijepit, sedangkan kabel merah dan kuning diujungnya memiliki plat di mana plat tercebut di tancapkan ke tanah sekitar CVT, seperti ditunjukkan Gambar 7. Kabel kuning dan merah memiliki panjang kabel yang berbeda, kabel merah biasanya memiliki panjang kurang 
lebih 20 meter sedangkan kabel kuning memiliki panjang kurang lebih 10 meter. Penancapan platpun diharuskan berjarak antara hijau dengan kuning $\pm 5-10$ meter sedangkan jarak antara kuning dan merah $\pm 5-10$ meter, diharuskan antar warna tersebut berjarak $\pm 5-10$ meter.

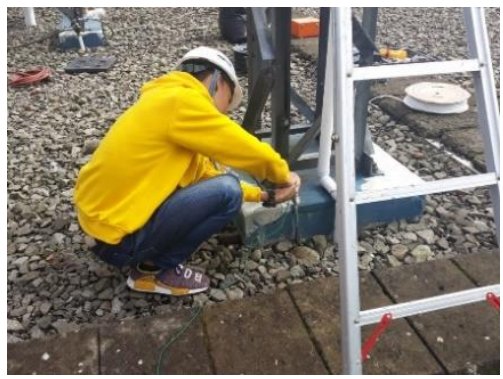

Gambar 7. Pengujian tahanan pentanahan CVT Phasa S Bay Busbar 2150 kV di GI PT. XYZ Indonesia

\subsubsection{Pengujian Tahanan Isolasi}

Pengujian tahanan isolasi dilakukan untuk mengecek atau mengetahui apakah isolator yang memisahkan sisi primer dan sisi sekunder berkerja dengan baik atau tidak. Memahami respons impuls karakteristik CVT sangat penting untuk menganalisis kesalahan isolasi internal dari CVT [9]. Isolator berfungsi sebagai pemisah atau penghambat tegangan yang berada antara sisi primer dan sisi sekunder. Isolator ini sangat berguna untuk menghambat tegangan yang mengalir dari sisi primer ke sisi sekunder dan mengurangi induksi yang terjadi karena tegangan yang besar pada sisi primer. Isolator berbentuk seperti piringan, memiliki banyak jenis bahan tetapi kali ini isolator pada CVT Phasa S Bay Busbar $2150 \mathrm{kV}$ di GI PT. XYZ Indonesia terbuat dari keramik porcelain dan berjumlah 23 piringan (isolator).

Pada CVT terdapat terminal box yang berada pada sisi sekunder, di mana didalam terminal box ini terdapat inti (core) yang berfungsi sebagai metering dan relay, seperti ditunjukkan Gambar 8. Pada terminal terdapat 4 inti yaitu sekunder 1a, sekunder 1n, sekunder $2 \mathrm{a}$, dan sekunder $2 \mathrm{n}$. Sekunder 1a dan $1 \mathrm{n}$ berfungsi sebagai relay, sedangkan sekunder $2 \mathrm{a}$ dan $2 \mathrm{n}$ berfungsi sebagai metering. Untuk pengujian tahanan isolasi digunakan sekunder 1a dan 2a.

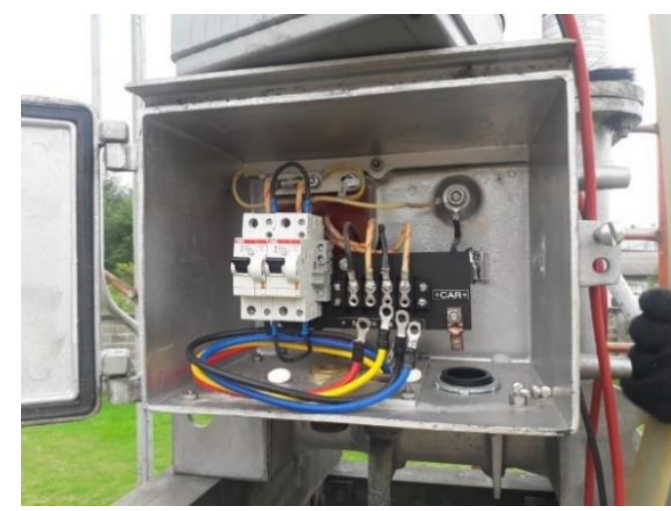

Gambar 8. Core terminal box CVT Phasa S Bay Busbar 2150 kV di GI PT. XYZ Indonesia

Pada pengujian tahanan isolasi ini diuji dengan alat uji tahanan isolasi yaitu Kyoritsu High Voltage Insulation Tester Model 3125, seperti ditunjukkan Gambar 9. Hasil pengujian 
tahanan isolasi diharuskan sesuai dengan standar dari Surat Keputusan Direksi yang mana telah diberitahukan tentang nominal batas kelayakan tahanan isolasi CVT. Pada sisi teori menurut Surat Keputusan Direksi diketahui bahwa hasil pengujian tahanan isolasi harus $>1 \mathrm{M} \Omega$ per $1 \mathrm{kV}$ penginjeksian, jika hasil pengujian pentanahan bernilai $>1 \mathrm{M} \Omega$ maka tahanan isolasi masih bagus.

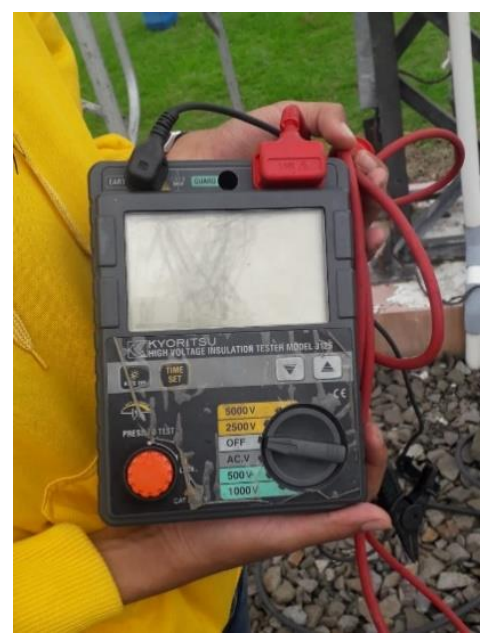

Gambar 9. Kyoritsu High Voltage Insulation Tester Model 3125

Pengujian tahanan isolasi pada CVT bergantung pada 4 bagian yaitu sisi primer, ground, inti sekunder 1a, dan inti sekunder 2a. Pengujian CVT dilakukan 6 kali pengujian, cara pengujianya ialah dengan menyambungkan masing - masing kabel yang berada pada alat uji tahanan isolasi yaitu Kyoritsu High Voltage Insulation Tester Model 3125, seperti ditunjukkan Gambar 10. Alat ini memiliki 2 kabel yaitu kabel merah dan hitam. Alat ini akan menginjeksi atau memberikan tegangan ke bagian yang disambungkan dan akan membaca hambatan $(\Omega)$, besar tegangan yang diinjeksi disesuaikan dengan pengujian.

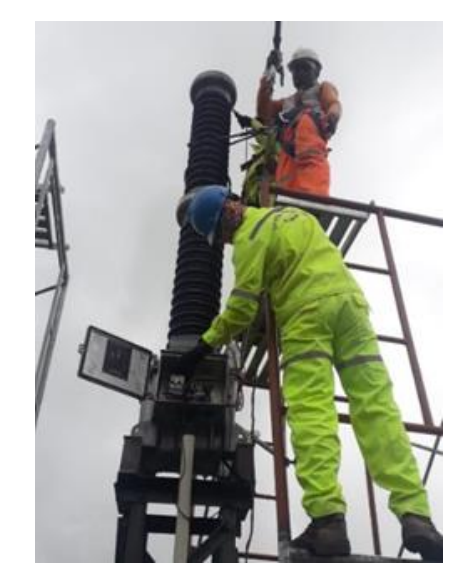

Gambar 10. Pengujian tahanan isolasi CVT Phasa S Bay Busbar 2150 kV di GI PT. XYZ Indonesia

\subsubsection{Pengujian Tan Delta}

Pengujian tan delta pada CVT dilakukan untuk mengetahui peningkatan nilai dari kapasitansi yang mengindikasikan adanya pemburukan pada isolasi yaitu kertas isolasi. Pada trafo tegangan yang menggunakan minyak untuk isolasinya, minyak memiliki nilai 
konduktansi yang cukup rendah dan nilai kapasitansi yang cukup tinggi, biasanya Pengujian tan delta dilakukan untuk mengetahui besarnya nilai faktor disipasi (tan delta) dan kapasitansi. Tan delta berprinsip bahwa setiap isolasi dalam keadaan murni bertindak sebagai kapasitor, pada sisi teori nilai tan delta yang bagus menurut SK Dir (Surat Keputusan Direksi) adalah $<0,5$.
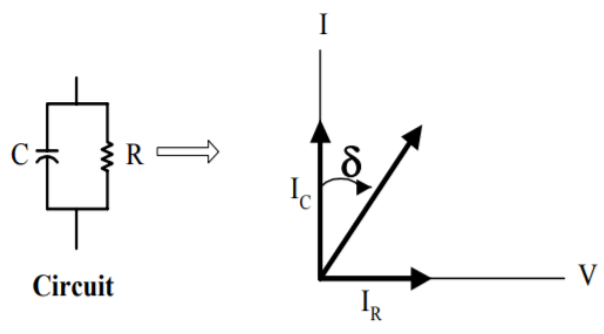

Gambar 11. Tan delta hubungan IC dan IR.

Seperti ditunjukkan Gambar 11, dalam kapasitor ideal, perbedaan sudut phasa antar verktor arus dan tegangan adalah $90^{\circ}$, begitu pula dengan isolasi kondisi yang ideal. Namun, jika isolasi memburuk yang disebabkan oleh kotoran dan arus yang mengalir melalui isolasi juga akan memiliki komponen resistif. Ini akan mngakibatkan kurangnya sudut arus atau yang sering disebut dengan rugi sudut (angle loss). Arus kapasitif murni biasanya yang keluar dari fase $90^{\circ}$ dan arus yang mengalir melalui isolasi. Jika sudut fase antara arus dan tegangan $<90^{\circ}$ maka akan memberikan nilai tingkat degradasi dalam isolasi, hal inilah yang meningkatkan arus resistif (IR). Tan dari sudut IC dan IR memberikan kita indikasi kondisi isolasi, makin tinggi tingkat loss maka makin tinggi tingkat kontaminasi isolasi [2].

Khusus untuk peralatan CVT pada umumnya faktor disipasi tidak dilihat, hanya pengukuran kapasitansi yang dilihat hasilnya. Ini terjadi karena CVT memiliki hambatan murni (resistansi murni), di mana arus dari hambatan tersebut menimbulkan faktor losis (rugi - rugi daya) yang akan menyebabkan tan delta menjadi $>0,5$ yang berarti tan delta akan menjadi buruk. Hal inilah yang menyebabkan CVT umumnya hanya di lihat nilai kapasitansinya saja. Pada sisi teori, nilai kapasitansi CVT phasa S bay busbar $2150 \mathrm{kV}$ di GI PT. XYZ Indonesia seharusnya memiliki nilai $<8300+10 \%$ ataupun $>8300-5 \%$ sesuai dengan standar papan nama nya (nameplate) seperti pada Gambar 5 atau bisa dilihat keterangannya pada kotak alat pengujian. Untuk menghitung nilai kapasitansi menggunakan alat pengujian tan delta yaitu Megger 4000, alat ini berbentuk 2 buah kotak besar dan berat yang saling dihubungkan dengan 2 kabel penghubung, seperti ditunjukkan Gambar 12. 


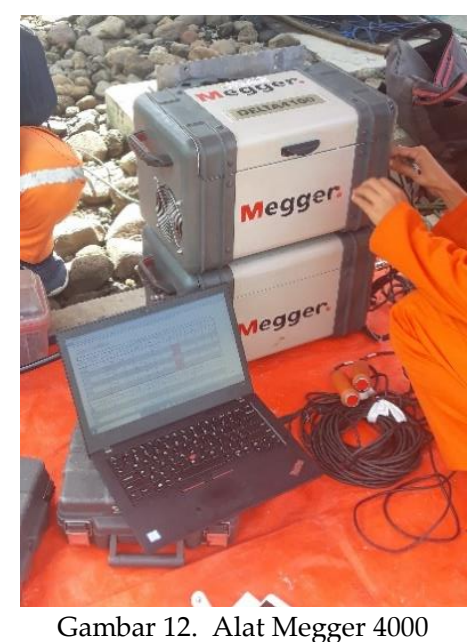

Cara kerja alat Megger 4000 untuk menghitung nilai kapasitansi adalah dengan menginjeksi tegangan sebesar $10 \mathrm{kV}$ ke CVT. Sebelumnya alat ini mendapat suplay dari listrik dan telah di sambungkan ke sebuah laptop. Laptop tersebut harus telah terinstal aplikasi khusus untuk pengukuran tan delta bernama DB Power. Kemudian sesuaikan template DB Power untuk pengujian CVT, aplikasi ini akan menampilkan sebuah template berupa tabel. Pada tabel nilai suhu tangki akan diisi oleh tim pengujian CVT terlebih dahulu, yang mana suhu tangki akan diisi sesuai dengan suhu CVT yang telah didapatkan atau diukur dengan alat khusus pengukur suhu yaitu alat Thermovisi. Setelah pengisian suhu tangki maka otomatis sub tabel suhu di bawahnya akan terisi sesuai atau sama dengan nilai suhu tangki tersebut.

Pengujian tan delta dengan alat Megger 4000 memiliki 2 cara yaitu GST - GND dan UST - R/B. Cara pengujian GST - GND adalah menggunakan kabel grounding, di mana kabel grounding Megger 4000 di pasang pada kabel grounding CVT dengan cara dijepit. Sedangkan untuk cara UST - R/B adalah dengan cara menyambungkan kabel R/B (Red or Blue) dari alat ke sisi sekunder dengan cara dijepit, dan tidak menggunakan grounding CVT (Capasitive Voltage Transformator), tetapi sebelumnya untuk cara UST - R/B sisi sekunder harus di pisah dengan sisi gelagar. Pemisahan dengan cara menarik tuas penghubung antara sisi sekunder dan sisi gelagar, ini dilakukan agar tidak ada tegangan yang mengalir pada sisi gelagar. Untuk pengujian CVT $150 \mathrm{kV}$ ini cara pengujian tan deltanya menggunakan cara GST - GND. 


\section{Hasil dan Pembahasan}

Pada hasil dan pembahasan untuk mengetahui kelayakan performa dari CVT phasa S bay busbar $2150 \mathrm{kV}$ di GI PT. XYZ Indonesia ini dilakukan 3 pengujian dan telah didapatkan nilai hasil pada masing masing pengujian, di antara sebagai berikut :

\subsection{Pengujian Pentanahan}

Gambar 13 menunjukkan langkah - langkah yang harus dilakukan pada pengujian pentanahan CVT Phasa S Bay Busbar 2150 kV di GI PT. XYZ Indonesia :

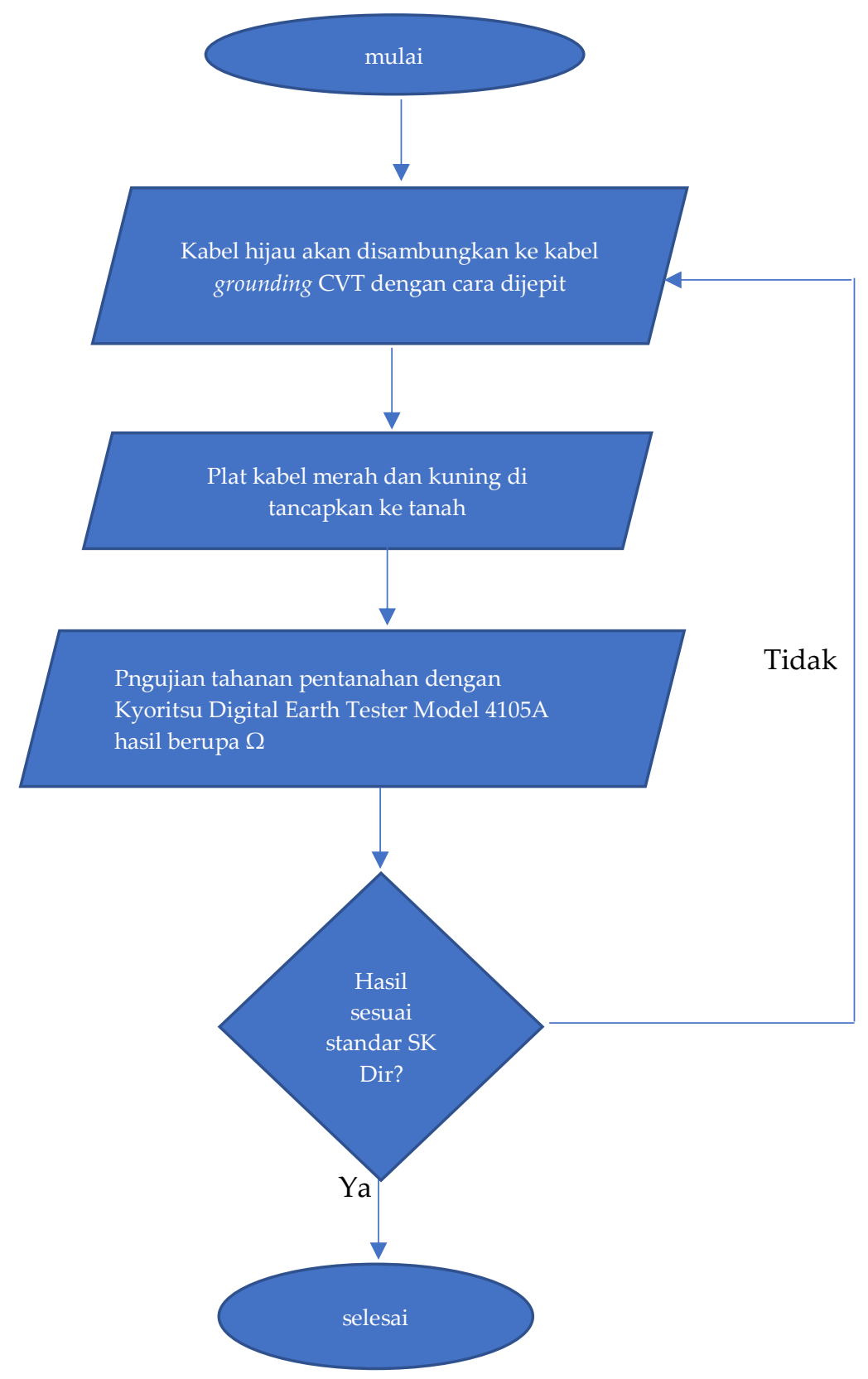

Gambar 13. Diagram alir pengujian pentanahan 
Dari langkah - langkah yang dilakukan, pada pengujian pentanahan CVT phasa S bay busbar $2150 \mathrm{kV}$ di GI PT. XYZ Indonesia ini dihasilkan tahanan pentanahan yang ditunjukkan pada Tabel 1 :

Tabel 1. Hasil pengujian tahanan pentanahan CVT Phasa S Bay Busbar 2150 kV di GI PT. XYZ Indonesia

\begin{tabular}{|c|c|c|}
\hline \multirow{2}{*}{ Titir Ukur } & \multicolumn{2}{|c|}{ Phasa S } \\
\cline { 2 - 3 } & Standar & Hasil \\
\hline Tahanan Pentanahan & $<1 \Omega$ & $1,35 \Omega$ \\
\hline
\end{tabular}

Berdasarkan hasil pengujian tahanan pentanahan, CVT Phasa S Bay Busbar $2150 \mathrm{kV}$ di GI PT. XYZ Indonesia memiliki nilai yang lebih besar dari standar SK Dir $(<1 \Omega)$ yaitu $1,35 \Omega$, maka bisa disebut bahwa terjadi anomali (gangguan) pada sistem grounding CVT. Tetapi nilai tersebut tenyata dikenal wajar, hal ini terjadi karena tingkat kelembapan tanah yang berbeda beda di setiap gardu induk. Maka tim penguji memiliki standar sendiri yaitu hasil harus $<1,5 \Omega$. Standar ini sudah turun temurun dari generasi tim pengujian dan sudah terbukti tidak terjadinya anomali (gangguan). Maka dapat dikatakan tahanan pentanahan CVT Phasa S Bay Busbar 2150 kV di GI PT. XYZ Indonesia masih layak atau berkerja dengan baik. 


\subsection{Pengujian Tahanan Isolasi}

Gambar 14 menunjukkan langkah - langkah yang harus dilakukan pada pengujian tahanan isolasi CVT phasa S bay busbar $2150 \mathrm{kV}$ di GI PT. XYZ Indonesia.

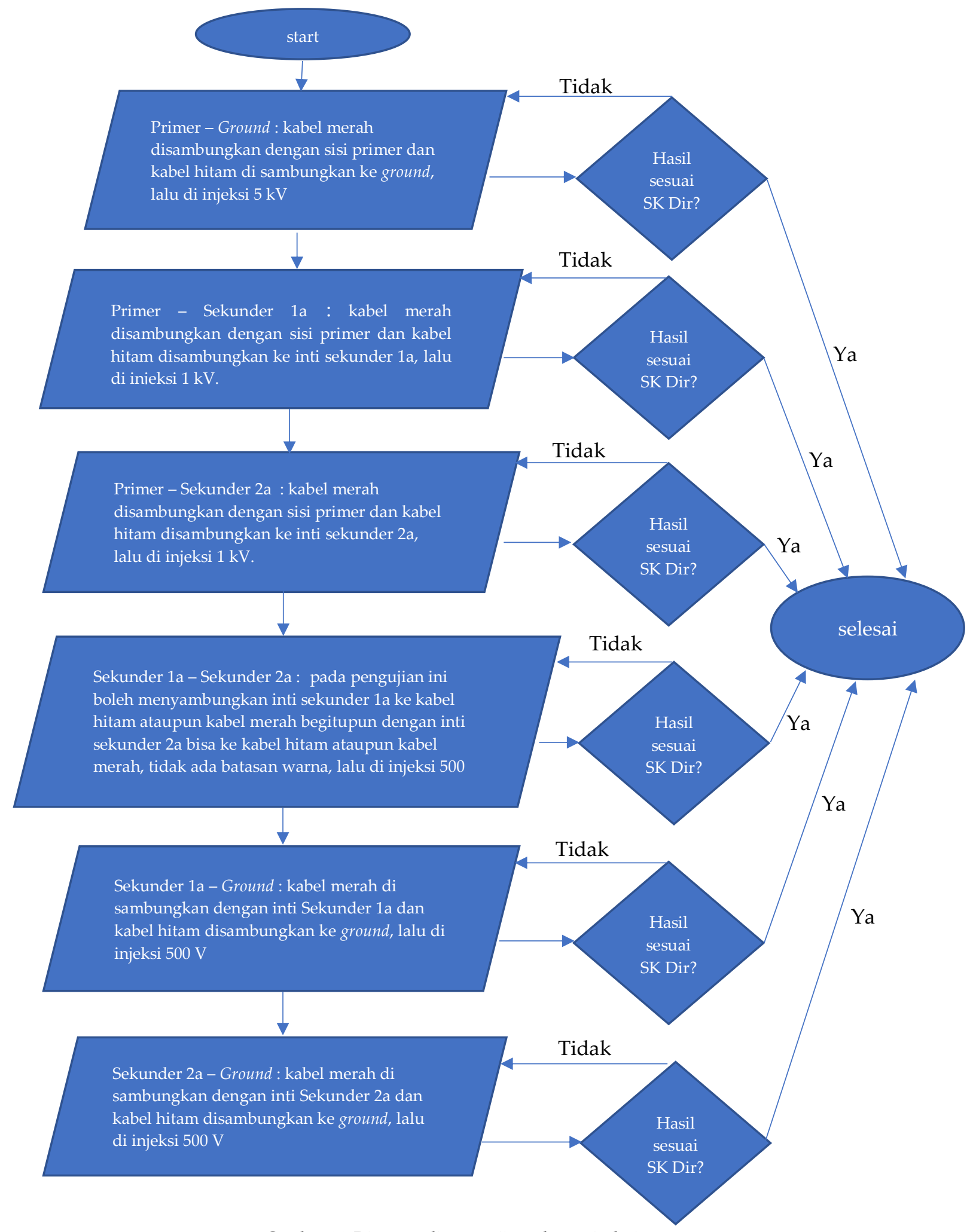

Gambar 14. Diagram alir pengujian tahanan isolasi 
Dari langkah - langkah yang dilakukan, pada pengujian tahanani isolasi CVT phasa S bay busbar 2150 kV di GI PT. XYZ Indonesia dihasilkan nilai sepeti ditunjukkan Tabel 2.

Tabel 2. Hasil pengujian tahanan isolasi CVT Phasa S Bay Busbar 2150 kV di GI PT. XYZ Indonesia

\begin{tabular}{|c|c|c|}
\hline Titik Ukur & Tegangan Uji & Phasa S \\
\cline { 1 - 2 } & & Hasil Ukur \\
\hline Primer - Ground & $5 \mathrm{kV}$ & $>1000000 \mathrm{M} \Omega$ \\
\hline Primer - Sekunder 1a & $1 \mathrm{kV}$ & $>10000 \mathrm{M} \Omega$ \\
\hline Primer - Sekunder 2a & & $>10000 \mathrm{M} \Omega$ \\
\hline Sekunder 1a - Sekunder 2a & \multirow{2}{*}{$500 \mathrm{~V}$} & $>1000 \mathrm{M} \Omega$ \\
\hline Sekunder 1a-Ground & & $>1000 \mathrm{M} \Omega$ \\
\hline Sekunder 2a-Ground & & $>1000 \mathrm{M} \Omega$ \\
\hline
\end{tabular}

Dilihat dari Tabel 2 terlihat bahwa hasil pengujian tahanan isolasi CVT Phasa S Bay Busbar 2150 kV di GI PT. XYZ Indonesia sesuai dengan Surat Keputusan Direksi. Di mana hasil dari 6 pengujian tersebut $>1 \mathrm{M} \Omega$ per $1 \mathrm{kV}$ penginjeksian. Maka dapat dikatakan tahanan isolasi CVT Phasa S Bay Busbar 2150 kV di GI PT. XYZ Indonesia masih layak atau berkerja dengan baik. 


\subsection{Pengujian Tan Delta}

Gambar 15 menunjukkan langkah - langkah yang harus di lakukan pada pengujian tan delta CVT phasa S bay busbar $2150 \mathrm{kV}$ di GI PT. XYZ Indonesia.

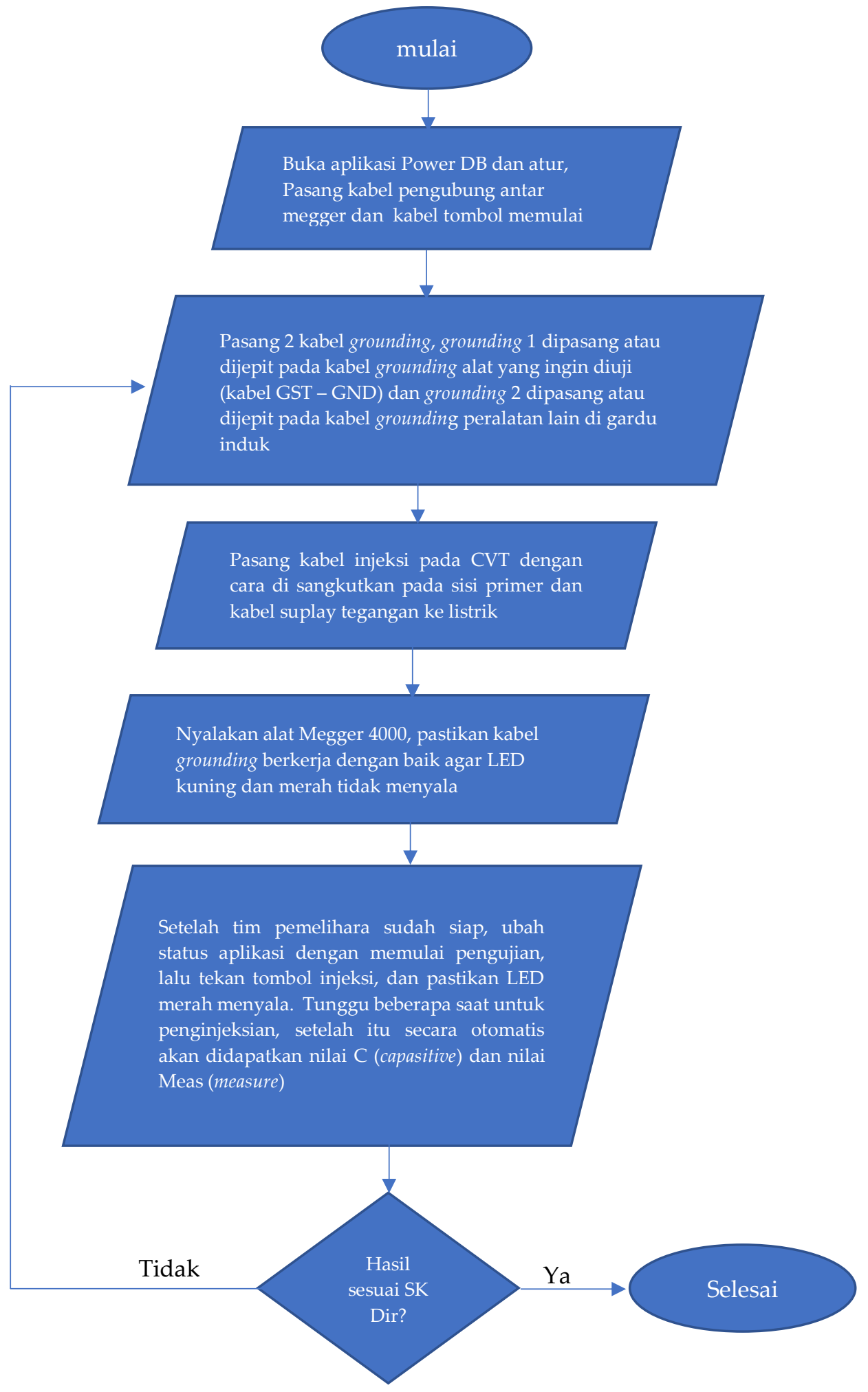

Gambar 15. Diagram alir pengujian tan - delta 
Kabel Grounding 2 berfungsi sebagai penjaga atau proteksi jika terjadi lonjakan tegangan agar terbuang melalui kabel grounding tersebut. Pada saat menyalakan alat Megger 4000, pada alat ini terdapat 2 LED berwarna merah dan kuning. Kuning untuk status grounding dan merah untuk status injeksi tegangan. Jika kuning menyala itu berarti bahwa kabel grounding belum berkerja dengan baik, maka pastikan kabel grounding berkerja dengan baik agar LED kuning tidak menyala. Kabel grounding biasanya tidak berkerja dengan baik dikarenakan kotoran yang berada pada kabel grounding alat, hal ini bisa di atasi dengan mengesek - gesek penjepit pada kabel grounding peralatan tersebut. Sedangkan untuk kabel merah jika menyala berarti injeksi sedang berlangsung. Maka ketika menyalakan alat Megger 4000 perhatikan 2 LED tersebut, pastikan bahwa Kedua LED padam. Untuk memulai pengijeksian, pastikan bahwa tim pemelihara CVT lainnya sudah siap dan tidak memegang kabel injeksi maupun CVT, agar tim penguji tidak tersengat tegangan dan tidak terjadi hal yang tidak diinginkan.

Dari langkah - langkah yang dilakukan, pada pengujian tan delta CVT phasa S bay busbar 2150 kV di GI PT. XYZ Indonesia didapatkan nilai seperti ditunjukan Tabel 3.

Tabel 3. Hasil pengujian tan delta CVT Phasa S Bay Busbar 2150 kV di GI PT. XYZ Indonesia

\begin{tabular}{|c|c|c|c|c|}
\hline \multirow{2}{*}{ Titik Ukur } & \multirow[t]{2}{*}{ Titik Pengujian } & \multirow{2}{*}{ Tipe Pengujian } & \multirow{2}{*}{$\begin{array}{l}\text { Kapasitansi } \\
\text { Nameplate }\end{array}$} & Phasa S \\
\hline & & & & Hasil \\
\hline Tan delta $(\%)$ & \multirow{2}{*}{ C total } & \multirow{2}{*}{ GST - GND } & \multirow{2}{*}{8300} & 0,37 \\
\hline Capasitance $(\mathrm{pF})$ & & & & $8.722,05$ \\
\hline
\end{tabular}

Terlihat bahwa hasil pengujian tan delta CVT Phasa S Bay Busbar $2150 \mathrm{kV}$ di GI PT. XYZ Indonesia nilai kapasitansinya ialah $8.722,05$ yang mana sesuai dengan Surat Keputusan Direksi (nilai kapasitansi $<8300+10 \%$ ataupun $>8300-5 \%$ ). Maka dapat dikatakan pengujian tan delta CVT Phasa S Bay Busbar 2150 kV di GI PT. XYZ Indonesia masih layak atau berkerja dengan baik.

\section{Kesimpulan}

Kelayakan performa CVT dapat diketahui dengan melakukan 3 pengujian yaitu pengujian pentanahan, tahanan isolasi dan tan delta. Berdasarkan analisis menggunakan 3 metode pengujian tersebut serta dilihat dari kondisi fisiknya, CVT Phasa S Bay Busbar 2 $150 \mathrm{kV}$ di GI PT. XYZ Indonesia masih dinyatakan layak untuk digunakan. Hasil pengujian tahanan pentanahan memiliki nilai yang lebih besar dari standar SK Dir $(<1 \Omega)$ yaitu 1,35 $\Omega$, maka bisa disebut bahwa terjadi anomali (menurut SK Direksi), Tetapi nilai tersebut bisa dikatakan layak untuk digunakan menurut Tim Pengujian, hal tersebut sering terjadi pada pengujian pentanahan di lapangan (gardu induk) dikarenakan sulitnya pencarian tahanan pentanahan yang sesuai Keputusan Direksi. Hal ini terjadi karena tingkat kelembapan tanah yang berbeda beda di setiap gardu induk, sehingga tim penguji memiliki standar sendiri yaitu hasil tahanan harus $<1,5 \Omega$.

\section{Daftar Pustaka}

[1] D. Malendes, "Pengukuran Tahanan Pentanahan Transformator Daya" Skripsi S1, Teknik Elektro, Politeknik Negeri Manado, 2015. 
[2] "Buku Pedoman Pemeliharan Trafo Tegangan (CVT)", Surat Keputusan Direksi, PT. PLN (Persero), Jakarta 2014.

[3] N. Afif, "Studi Perancangan Ferroresonance suppression circuit (FSC) oada Capacitive Voltage Transformator (CVT) Saluran Transmisi 150 KV", Skripsi S1, Jurusan Teknik Elektro, Fakultas Teknologi Industri, Institut Teknologi Sepuluh Nopember, 2016.

[4] J. Pramono, "Makalah Teknik Tenaga Listrik, Transmission of Electrical Energy (Transmisi Tenaga Listrik)", Departemen Teknik Elektro, Fakultas Teknik, Universitas Indonesia, $2010 . \quad$ [Online]. https://www.yumpu.com/id/document/read/4408747/makalah-teknik-tenaga-listriktransmission-of-electrical-energy. [Diakses 5 April 2021].

[5] "Transmisi Tenaga Listrik: Modul Bahan Ajar SMK Kelas XI SM 3 Kurikulum 2013 Teknik Jaringan Transmisi Tenaga Listrik", PPPPTK BMTI, Departemen Pendidikan Nasional, 2013. [Online]. http://repositori.kemdikbud.go.id/8836/1/JARINGANTRANSMISI-TENAGA-LISTRIK-XI-3.pdf. [Diakses tanggal 5 April 2021].

[6] F. J Tasiam, "Proteksi Sistem Tenaga Listrik", Univesitas Negeri Manado, 2017. [Online], http://repository.unima.ac.id/bitstream/123456789/238/1/PROTEKSI\%20SISTEM\%20 TENAGA\%20\%20\%20\%20LISTRIK-COMBINE.pdf. [Diakses 5 April 2021].

[7] R. Syahputra, "Transmisi Dan Distribusi Tenaga Listrik", LP3M Universitas Muhammadiyah Yogyakarta, 2017. [Online], http://repository.umy.ac.id/bitstream/handle/123456789/13686/RAMADONI_Transm isi\&Distribusi.pdf?sequence=1. [Diakses 5 April 2021].

[8] A. Halim, C. H. Lim, and S. Mekhilef, "Investigation of Transient Performance of Capacitor Voltage Transformer", Proc. of 2006 IEEE International Power and Energy Conference, Nov. 28-29, 2006.

[9] L. Shoubao, H. Yucheng, X. Zhonghao, F. Yuan, T. Li, "Study on Impact Response Characteristics of Capasitive Voltage Transformator", Journal of Physics: Conference Series, vol. 1486, pp. 1, April 2020.

[10] H. Sujatmiko, "Analisis Kerugian Daya Pada Saluran Transmisi Tegangan Ekstra Tinggi 500 Kv Di P.T. Pln (Persero) Penyaluran \& Pusat Pengaturan Beban (P3b) Jawa Bali Regional Jawa Tengah \& Diy Unit Pelayanan Transmisi Semarang", Jurnal Teknik Elektro, vol. 1, no.1, 2009.

[11] M. Budiyanto. (2018). Mengenal Tegangan Listrik. Sarjana Terapan Teknologi Rekayasa Elektro Departemen Teknik Elektro dan Informatika UGM. https://listrik.sv.ugm.ac.id/2018/06/25/mengenal-tegangan-listrik/.

[12] Praseto, M. T. dan Kiswanto, A., “Analisis Data DFR (Data Fault Recorder) Sebagai Alat Bantu Penentu Jenis Penyebab dan Lokasi Gangguan Saluran Udara Tegangan Tinggi Satu Fasa Ke Tanah," Tesis, Universitas Muhamadiyah Semarang. http://repository.unimus.ac.id/2877/ 